\title{
THE IMPACT OF THE AKSU BATTLE ON FERGHANA
}

\author{
Yuldashev Saidanvarbek Bahromjon ugli \\ Base doctoral student of Fergana State University, Republic of Uzbekistan
}

Article DOI: https://doi.org/10.36713/epra4917

\begin{abstract}
The article examines the Aksu battle, an important event in the history of Fergana, based on historical sources and literature. The political events in pre-war Fergana are reflected in the conflict between the interests of the Arab Caliphate, the Tang Empire, Tibet and the Turkish Khanate in the valley. The influence of the events that took place in Fergana in 715-716 on the Battle of Aksu is also described. The issues including Qutayba ibn Muslim's march into the valley in 715, the fled of the Ikhshid of Fergana to the province of Ansi as a result and his seeking military assistance from the Tang Empire, Abdullah Yashkuri's departure to Aksu through Fergana, his being taken captive by the Chinese, and the Turkashes taking control of northern Fergana are studied.
\end{abstract}

KEYWORDS: Fergana, Qutayba ibn Muslim, Alutar, Ikhshid, Boshak, Sulukhan, Zhang Xiaousun, Northern Fergana, Tibet, Aksu, Yakka Ariq.

\section{INTRODUCTION}

By the beginning of the VIII century, the interests of the Arab Caliphate, the Tang Empire, Tibet and the Turkish Khanate clashed in the Fergana Valley. The Arab Caliphate was trying to annex the region, and the Turkish Khanate did not want to lose this vassal of hers. During this period, Tibet, which got more powerful than she was before, invaded East Turkestan and began to conquer Central Asia. The Tang Empire of China had also set itself the goal of subjugating Fergana. The battle of Aksu took place in a situation of these conflicts of interest.

\section{MATERIAL AND METHODS}

The article is based on generally accepted methods - historical, comparative-critical analysis, consistency, objectivity, and based on historical sources and literature, studies the Battle of Aksu, an important event in the history of Fergana. The political events in pre-war Fergana show the conflict between the interests of the valley's Arab Caliphate, the Tang Empire, Tibet and the Turkish Khanate. The influence of the events of 715-716 in Fergana on the Battle of Aksu is also described.

The rulers of Fergana, in difficult situations, sometimes formed an alliance with the Turks, sometimes with the Chinese, and tried to protect their property from the Arab invaders. In this regard, we would like to dwell on the issue of the Tang Empire's assistance to the people of Fergana. In his treatise, A.N. Bernstam noted that relying on China in the fight against the Arabs was costly for the Fergana people, in exchange for which Fergana lost its independence, albeit temporarily, in the eighth century (until 757) and twice became part of the Chinese prefectures. [3. p. 25].

However, L. N. Gumilev and B. G'. Gafurov deny that China was involved in the fight against the Arabs. L. N. Gumilev notes that the Tang government did not send any military units to help the Fergana and Sogdians. According to him, the emperor believed that the people of Central Asia would inevitably incline towards China, fearing the plunder of the Arabs and Tibetans. B. G'. Gafurov writes that Chinese emperors promised Central Asian rulers help in the fight against the Arabs, but in return for these unfulfilled promises, they were required to be vassals of China. [5. p. 23]. Data from historical sources have shown that A.N. Bernstam's view which acknowledges the help of Tang Empire to the Fergana people is more accurate than the other hypothesis.

Unfortunately, there is almost no information about the "Battle of Aksu" in research works published in our country. We can learn about this battle through Chinese sources and foreign 


\section{EPRA International Journal of Research and Development (IJRD)}

researches based on them $[15 ; 26 ; 27]$. Since the Arab military campaigns in Fergana had a great impact on this conflict, we would like to dwell on these marches first.

In the sources created in the Arabic-Persian language, important information about the military campaigns of the Arabs to Fergana under the leadership of Qutayba ibn Muslim in 713-715 has survived up until our time. To date, the military campaigns of the Arabs have been covered only on the basis of Arabic-Persian sources. However, Chinese sources also contain information about the Arab marches to Fergana and the historical events that took place at that time. In his work, the Chinese historian Sima Kuang wrote the stories of the Arab invasion into the valley [27. 211. p.6713].

Qutayba ibn Muslim, who had extensive military experience, replenished his army at the expense of the inhabitants of the occupied provinces, and in 713 turned his attention to Chach and Fergana. His main goal was to strike at the militaryly strong members of the anti-Arab coalition - the Chachis, the Fergana people and the Turks. Qutayba gathered a large army and began to attack in two directions. The first (northern) group of Keshliks, Nasafis and Khorezmians mobilized for the war was sent to Chach under the leadership of Qutayba's brother Abdurahman. [6. p. 185; 18. IV. p. 522]. The second (southern) group, commanded by Qutayba and composed mainly of Arabs, marched on Khojand and Fergana. [5. p. 20]. In our opinion, the importance of the march to Fergana can be seen from the fact that it was personally led by Qutayba. In addition, this indicates the presence of serious forces against the Arabs in Fergana.

There is no detailed information in the sources about the actions of the military forces sent to the north. They captured the city of Chach and set fire to many of the settlements around it. The southern group, led by Qutayba, captured Khojand and approached Kasan. Here the soldiers sent to Chach returned and joined Qutayba's army [28. p. 205]. Sources say that Qutayba appointed an Arab deputy to Fergana, and Arab settlements were established in Chach and Fergana. But despite these victories of Qutayba, the Chachs and Fergana people did not surrender to the enemy and continued to resist [5. p. 20].

In 714, Qutayba once again attacked Chach. He captured Chach and marched to Isfijob (now Sayram). The main purpose of this was to capture the city and block the main way for the Turks to come to the aid of the Central Asians.

At the beginning of 715, Qutayba marched on Fergana for the second time. The ruler of Fergana was forced to flee. Although the sources do not give details of this march, it can be assumed that the Arabs occupied a large part of Fergana (southern and eastern regions).

In his "Kitab al-Futuh" Ibn 'Asam al-Kufi narrates the marches of Qutayba ibn Muslim into Fergana. The work states that in 715 the Arabs fought against the ruler of Fergana named Boshak. The fortress of Boshak, called Kazah, was besieged by Qutayba for seven months. At the end of the siege, the Arabs made peace with Boshak. Believing them, Boshak was killed by the order of Qutayba as soon as he left the fortress [30. p. 167]. Perhaps Boshak was the Fergana Ikhshid who asked the Chinese for military assistance.

Chinese sources indicate that the Arabs invaded Fergana and that the defeated Fergana Ikhshid sought help from the Chinese. [12. p. 235]. According to him, in 715, when the Arabs occupied the valley, Alutar came to the throne, and Fergana Ikhshidi fled to Kucha (a Chinese protectorate called Ansi). The Chinese help the Ikhshid under the command of Zhang Xiaousun [14. p. 148-149]. After Zhang Xiaousun defeated the forces of Alutar and the Arabs in northern Fergana, Ikhshid rule was restored there. The Chinese, together with the Ikhshid, occupied three cities and one fortress in Fergana [26. p. 276]. Alutar flees to the mountains [15. p. 88-89]. But historical sources do not mention the names of the three cities occupied by the Chinese.

Analyzing the data al-Kufi provided and the above Chinese sources, many details about Qutayba's march to Fergana, including the coming to power of Fergana ruler Alutar with the help of the Arabs in 715 , show that there was a struggle between Boshak and Alutar when Qutayba invaded into the land.

In the fall of 714, the Tibetan leader Cree Giggs and his vassal Bon Dargyal made several raids on the banks of the Yellow River. Their attacks on the other side of the Lin Tao River and the Lan Choudan Wei River - Vyenga - were repulsed by the Tang troops. But according to Chinese sources, the Tibetans began to prepare for major military campaigns from 710 onwards. In particular, they built fortresses, built a bridge over the Yellow River and stationed their armies called "Lonely Mountain" and "Nine Edges". [15. p. 80-81]. But in an unexpected situation, the Tibetans sent an offer of a peace treaty to the Tang Empire. However, Sima Kuang noted that Tibetans continued to attack borders every year [27. 211. p. 6706]. As relations with China deteriorate, Tibet's interest in Fergana begins to grow.

Tibetan relations with the Arabs became more active during the reign of the Khurasan viceroy 


\section{EPRA International Journal of Research and Development (IJRD)}

Jarrah ibn Abdullah al-Hakami (717-719). According to al-Ya qubi, the envoys of al-Tubbat came to alJarrah ibn 'Abdullah asking him to send someone to inform them about Islam. He sent al-Sulayt ibn 'Abdullah al-Hanafi to al-Tubbat [17. II. p. 317]. In this way, the Tibetans tried to form an alliance with the Arabs against the Tang Empire. Meanwhile, the Tibetans were crossing the Yellow River and plundering the lands of the Tang Empire to capture the Torim oasis.

As a result of these events, in 717, a major conflict broke out in the Aksu region between the Arabs, their allies the Tibetans, the Turkashes and the Chinese. The defeat of the Arabs by the Chinese in Fergana in 715 also played an important role in this conflict. Although Muslim sources do not directly state that the Arabs were led by Abdullah ibn Muammar al-Yashkuri in the Battle of Aksu, there is information that Abdullah al-Yashkuri fought against the Turks in eastern Turkestan and was taken prisoner. Balazuri describes this incident as follows: [Later] al-Jarrah sent 'Abdullah ibn Mu'ammar alYashkuri to Mawarounnahr. He tried to cross the [interior] of the enemy country and enter as-Sin [country]. [But] the Turks took him imprisoner. ['Abdullah] managed to get rid of them [by giving money] and was released and came to al-Shash [2. p. 49]. 'Abdullah ibn Muammar al-Yashkuri wanted to cross Fergana through the Tien Shan Mountains and to reach Kashgar. There the Eastern Turks and the Qarluqs may have been taken prisoner in a clash with a force composed of the Chinese. He was released from captivity for a large sum, as mentioned in the source.

\section{RESULTS}

In 717, the Arabs occupied two cities in Aksu, a Chinese protectorate, with their allies, the Turks and the Tibetans. Chinese commander in Central Asia Tang Jiahui sent two troops against the Arabs. The first was a Chinese infantry led by Tang Jiahui himself, and the second was a force made up of cavalry led by Ashina Hsien.

After the assassination of the Eastern Turkic khagan Qapagan Qaghan (692-716) in 716, the Turkashes were led by Sulukhan (Qopishchur). According to Chinese sources, 200,000 were initially under his command [31: 486-p]. It was Sulukhan who led the Turkashes in the Battle of Aksu. The Chinese were led by Ashina Hsien, who was given the status of "General Protector for the Reconciliation of the West" by the Jiangxi and Tang empires. [27: 211:672-p]. Ashina Hsien led the "Three Qarluqs" in conquests against the Arabs and the Turks. The Tang army, consisting only of Turks, drove the allies out of eastern Turkestan. Most of the Arab soldiers were taken prisoner. The captives were released after the Khilafah payed tribute to them in gold. As a result of this battle, the Turkashes came under Chinese protection and later took part in the battles against the Arabs in Fergana.

Meanwhile, Lung Yu's military governor, Kuo Chihyun, defeated the Tibetans at the banks of Yellow River. The Tarim oasis was liberated from the Tibetans by Tang troops.

As a result of the Aksu battle, Fergana was divided into two parts. The north fell into the reign of Turkashes and the south to the Arabs. This is also confirmed by Chinese sources. Hoi Chao, who came to Fergana in 727 , also states that only the southern part of the Fergana Valley was under Arab rule: "We marched east from Samarkand and reached to the state of Fergana. [In this country] there were two rulers [wang] in this land, they were separated by a large river called Fu-yu [Syrdarya] which flows through it. The ruler on the south of the river obeys the Arabs [daishi, dashi], and the ruler on the north obeys the Turks [tujyue]." [20. p. 54].

\section{CONCLUSIONS}

The result of the battle of Aksu was that neither side was able to achieve an absolute victory. Although the Arabs were driven out of northern Movarounnahr, they retained the southern districts of Fergana under their rule.

Although the Chinese failed to take control of Fergana, they drove Tibetans out of East Turkestan and secured their borders to some extent.

The Chinese took control over Turkashes from Arab influence and later they defeated their former allies, the Arabs in Fergana. The Turkash Khagan was awarded by the Chinese emperor and the city of Suyob was gifted to him. The Turkshes, with the help of the Chinese, carried out looting raids on the Arab territories in Mawarannahr. In Fergana, the Turkashes took control of the northern districts.

Although the Fergana people lost part of the valley in their struggle against the Arabs, the struggle against the Arabs continued until the beginning of the IX century.

\section{REFERENCES}

1. Abu Bakr, Narshahi. (1991). "History of Bukhara". Translated from persian by A.Rasulev. Responsible editor A.Urinbaev // Heritage. Tashkent. Kamalak. p.p: $98-152$.

2. Al-Balozuri, Abu-l-'Abbas Ahmad Ibn Yahya. (2017). "Futuh al-buldon". (Conquest of Khorasan). Foreword, Arabic translation, author of comments, annotations and indicators Sh.S. Kamoliddin. Toshkent. p. 235. 


\section{EPRA International Journal of Research and Development (IJRD)}

3. Bernshtam, A.N. (1951). "Ancient Fergana (Popular science essay)". Tashkent. Publishing house of the Academy of Sciences of the USSR. $p$. 49.

4. Bolshakov, O.G. (2010). "The history of the Caliphate". Vol. 4. Apogee and fall. Moscow. Eastern Literature RAS. p. 369.

5. Gafurov, B.G. (1989). "Tajiks: The Most Ancient, Ancient and Medieval History". Book II. Dushanbe. Irfon. p. 386.

6. History of at-Tabari. (1987). Trans. with arab. V. I. Belyaeva with add. O.G. Bolshakova, A.B. Khalidov. - Tashkent. Fan. p. 440

7. Ja kubi. (2011). "Book of Countries (Kitab alBuldan)". Introductory page, trans., Comments and indexes by L.A. Semenov. Moscow. Eastern Literature. p. 372.

8. Махмудов, О.В. (2017). “Феномен Толедской школь и три этапа переводов”. Евразийский Союз Ученых. (12-1 (45)). 5-9 [Makhmudov, O.V. (2017). "The phenomenon of the Toledo school and the three stages of translation". Eurasian Union of Scientists. (12-1 (45)). p.p: 59 (in Russ)].

9. Махмудов, О.В. (2017). “Феномен Толедской школь и четыре этапа переводов”. Всеобщая ucтория. (3). 14-21 [Makhmudov, O.V. (2017). "The phenomenon of the Toledo school and the four stages of translation". General History. (3). p.p: 14-21. (in Russ)].

10. Al-Balazuri. (1866). "Liber expugnationis regionum”. Auctore Imamo Ahmed ibn Jahja ibn Djabir al-Belol, quem a codice Leidensi et codice Musei Britannici ed. M.J.de Goeje. Lungduni Batavorum. p. 1376.

11. Abu Djafar, Mohammed ibn Djarir at-Tabari. (1964). "Annales". Ed. M.J. de Goeje, I-III. Lugduni Batavorum. E.J.Brill.

12. Bai, Shouyi. (2002). "A history of Chinese Muslim". Vol. 2. Beijing. Zhongua Book Company. p. 327.

13. Chavannes, E. (2007). "Western Turks according to Chinese sources". Translated by M. Koç. Istanbul. Selenge. p. 495.

14. Chavannes, E. (1903). "Documents on the Western Tou-kiue (Turks)" // Proceedings of the Orkhon Expedition, vol. 6. SPb., p. 500.

15. Christopher, I. Beckwith. (1993). "The Tibetan empire in Central Asia: a history of the struggle for great power among Tibetans, Turks, Arabs and Chinese during the early middle ages". New Jersey. Princeton university press. p. 281.

16. El-Belâzurî, Ahmed b. Yahya. (2013). Futuh-ulBuldan. Translation Prof. Dr. Mustafa Benefit. Istanbul. Siyeryayinlari. p. 657.

17. Ibn Wadhih, qui dicitur al-Ja'qubi. (1883). "Historiae". Ed. M.Th.Haustma, pars 1, historiam ante-islamicam continents; pars 2, historiam islamicam continents. Lungduni Batavorum.

18. Ibn al-Athir. (1986). "History of Islam. El Kamil Fi't Tarikh". Translation. Yunus Apaydin. 12
Volumes. Istambul. Turkiye printing and publication.

19. Ibn el-Athiri. Chronicon quod perfectissimum inscribitur, ed.C.J.Tornberg vol.I-XIV, Upsaliae et Lugduni Batavorum, 1851-1876. [I - L.B., 1867; II - L.B., 1868; III - L.B., 1869; IV - L.B., 1870; V-L.B., 1871; VI-L.B., 1871; VII-L.B., 1865; VIII - L.B., 1862; IX - L.B., 1863; XL.B., 1864; XI-Ups., 1851; Suppl. 1871; XIIUps., 1853; Suppl. 1871; XIII - L.B., 1874; XIV - L.B., 1876].

20. Hye Ch'o. (1984). "Memoir of the pilgrimage to the Five Regions of India". Translation, text and editing by: Yang Han-Sung, Jan Yün-Hua and IIda Shotaro, Laurence W. Preston. Seul. Dangsan-Dong Yeongdeungpo-Ku. p. p: 134.

21. Makhmudov, O.V. (2017). "The Toledo Schoolearly center of investigation of the works Central Asian scholars in the Europe". Saarbrucken (Germany): Lambert Academic Publishing. p. 193. ISBN: 978-3-330-33405-2.

22. Makhmudov, O.V. (2017). "Some reasons about employees of the translator Domingo Gundisalvo in Toledo School". Austrian Journal of Humanities and Social Sciences. (1-2). p.p: 3-7. DOI: http://dx.doi.org/10.20534/AJH-17-1.2-3-7

23. Makhmudov, O.V. (2017). "Translations carried out in the Spanish translation centers (On basis of the works of scientists of antiquity and Muslim East)". Asian Journal of Multidimensional Research (AJMR). (6-2). p. p: 5-20.

24. Makhmudov, O. (2017). "Latin translations of the works Abū Bakr ar-Rāzi and their values in development of the modern sciences". History, Problems and Prospects of Development of Modern Civilization. (18). p. p: 534-538.

25. Makhmudov, O.V. (2017). "Toledo School in the period of King Alfonso X". Proceedings of the $1^{\text {st }}$ International Conference on History, Sociology and Philosophy. (1). p. p: 3-7.

26. Makhmudov, O. (2020). "The role of the Toledo as a center for the transfer of scientific knowledge of medieval Eastern scientists to Europe”. Евразийский Союз Ученых. [Evraziiskii Soyuz Uchenykh]. №. 6-8 (75). Pp. 13-16. DOI: $\quad$ 10.31618/ESU.24139335.2020.8.75.890

27. Mahmudov, O. (2020). "The beginning of the European renaissance". ERPA International Journal of Research and Development. Vol. 5 (7). $\begin{array}{lll}\text { Pp. 104-108. DOI: } & \end{array}$ https://doi.org/10.36713/epra4787

28. Marvin, C Whiting. (2002). "Imperial Chinese military history: $8000 B C-1912 A D$ ”. New York. Writes club press. p. 605.

29. Ssu-ma, Kuang. (1976). "Tzu chih t'ung chien". 10 vols. Peking. repr. Taipei.

30. The History of al-Tabari. (1990). Translated by Martin Hinds. - Vol. 23. New York. State University of New York Press. p. 271.

31. Yuldashev, S.B. (2019). "Ferghana in the VII century: It's development as a powerful state and 
its collapse”. History Reseach Journal. 2019. vol. 5. Issue 6. p. p: $2952-2964$.

32. Ahmad bin A'sam, Al-Kufi. (1991). "Kitab alfutuh”. Beirut. Dar Al-Adwaa. 8 jild.

33. Yengi Tangnoma. (2013). “"24 tarix» teki G'arbiy yurt tarixig'a ayit materiallar”. Urumchi. Shinjon xalq nashriyati. p. 798.

34. Усмонов, Б. (2019). “Админстративное устроисво Ферганы накануне $и$ в начале прихода амира Темура к власти". Евразийских Союз Ученых. (3-1(3)). 40-43. [Usmonov, B. (2019). "Administrative arrangement of Fergana on the eve and at the beginning of the coming of Amir Temur to power." Eurasian Union of Scientists. (3-1(3)). 40-43. (in Russ)]

35. Usmonov, B. (2019). "Ferghana in the Period of Amir Temur's Struggle for power (1360-1370)”. International Journal of Innovative Technology and exploring Engineering. Volume-9, Issue-2. p. p: 3180-3187.

36. Usmonov, B. (2019). "Inclusion of the Fergana valley into the state of Amir Timur". History Reseach Journal. Vol. 5. Issue 5. p.p: 1154-1158.

37. Usmonov, B. (2020). "On the dates of the military clashed between Sultan Ahmad Mirza and Umarshaikh Mirza". Asian Journal of Multidimensional Research. Vol. 9. Issue 5. p.p: 397-404. 